\title{
Energy efficiency and conservation for individual Americans
}

\author{
D. Pimentel · Jennifer Gardner - Adam Bonnifield - Ximena Garcia • \\ Julie Grufferman · Claire Horan · Julia Schlenker • \\ Emily Walling • Emily Rochon
}

Published online: 9 May 2008

(C) Springer Science+Business Media B.V. 2008

\section{Erratum to: Environ Dev Sustain (2007) \\ DOI 10.1007/s10668-007-9128-x}

Emily Rochon also co-authored this article and her name should appear in the list of co-authors.

The online version of the original article can be found under doi:10.1007/s10668-007-9128-x.

D. Pimentel $(\bowtie) \cdot$ J. Gardner · A. Bonnifield · X. Garcia · J. Grufferman ·

C. Horan · J. Schlenker · E. Walling · E. Rochon

Agriculture and Life Sciences, Cornell University, 5126 Comstock Hall,

Ithaca, NY 14853-0901, USA

e-mail:dp18@cornell.edu 